\title{
Place-Based Pedagogy and Indonesian National Curriculum: A Strategy Analysis for Forest and Javan Lutung Conservation in the Bromo-Tengger- Semeru National Park
}

\author{
Eni Hidayati* \\ Forestry Department \\ University of Mataram \\ Mataram, Indonesia \\ eni.hidayati@unram.ac.id \\ Wiwin Iswandi Djola \\ Island Ranger Community \\ Jalan Kebayan, Sumbawa Besar \\ West Nusa Tenggara, Indonesia
}

\author{
Ika Yuni Agustin \\ Department of Biology \\ Brawijaya University \\ Malang, Indonesia
}

Sitti Latifah

Forestry Department

University of Mataram

Mataram, Indonesia

\author{
Yanuar Andi Karisma \\ Island Ranger Community \\ Jalan Kebayan, Sumbawa Besar \\ West Nusa Tenggara, Indonesia
}

\begin{abstract}
Abstracy-The Javan Lutung (Trachypithecus auratus; Vulnerable - IUCN Red List) is a primate endemic to the islands of Java, Bali and Lombok in Indonesia. In East Java, Javan Lutung is found in the Bromo-Tengger-Semeru National Park (BTSNP). With increasing pressure toward this species and its habitat, it is important to develop conservation strategies. Place-based pedagogy presents opportunities to allow students to increase their appreciation of their local environment and foster ecological literacy. Using SWOT analysis, this study aims to recommend strategies for a placebased pedagogy in primary schools based on K13 Curriculum. To conduct the SWOT analysis, we reviewed the K13 curriculum and we collected data on stakeholders' perception, Javan Lutung distribution, and potential education sites. Our study suggests that Javan Lutung and forest conservation education is feasible to be implemented using the place-based pedagogy approach with collaborations among schools, teachers, non-government organizations and BTSNP. There are numerous themes from Grade 1st to Grade 6th relevant with fauna and flora conservation. Our reviews of the Indonesian national curriculum indicated that the K13 curriculum provides opportunities for students and teachers to be more locally contextual in their learning process. Conservation education practitioners should tap into this good opportunity in order to answer the challenge of ineffective environmental education in the formal education sector in Indonesia.
\end{abstract}

Keywords-Environmental Education, Javan Lutung, Placebased pedagogy, SWOT analysis.

\section{INTRODUCTION}

Javan Lutung (Ebony Leaf Monkey/Trachypitecus auratus) is listed as Vulnerable in the IUCN Redlist [1] and protected under the Indonesian Law since 1999. This species is endemic to the islands of Java, Bali, and Lombok, Indonesia. In East Java, Javan Lutung is found in the BromoTengger-Semeru National Park and its surrounding forest owned by Perhutani, a state-owned timber company. The main threats for this species are forest degradation and forest conversion into arable land. With increasing pressure toward its habitat, it is important to develop conservation strategies.

Providing education program can be a valuable way to raise awareness about a species and the threats as well as what can be done to save the species [2]. Furthermore, they [2] stated that it can also help to change perceptions and may therefore indirectly help towards conserving species. However, in various contexts in Indonesia, environmental education is unsatisfactory and temporary [3]. In the formal sector in Indonesia, young people are not currently exposed to effective environmental education [4].

Place-based pedagogy is a learning process where local environment and community is used as a starting point [5] enabling students to see the relevance of their learning and become more engaged in the process [6]. Supporters for place-based pedagogy argue that the advantages of this approach include: increasing students' appreciation of their local environment [7], fostering ecological literacy [8], strengthening connection and relations between schools or students with their community [9],support children's physical and mental health and well-being [10], and enhance environmental responsibility and resilience[11].

In Indonesia, with the implementation of the National Curriculum since 2013 (called K13), the room for a placebased pedagogy is widely open. Being revised and widely implemented across Indonesia with the 2018 revision version, the rooms for conservation ideas are even greater. The major refinement from the previous curriculum (called KTSP 2006) to the $\mathrm{K} 13$ is in its aims to develop not only the cognitive skills but also the spiritual, attitude and psychomotor competencies of students through activity-based learning processes divided into themes. One of the K13 curriculum characteristics is that schools are integral parts of the communities. Hence the K13 curriculum provides opportunities for students to learn from their communities and apply what they have learned to benefit the community [12]. This characteristic is in line with the place-based pedagogy concept. 
Combining place-based pedagogy concept and the K13 may provide opportunities for a more effective environmental education. A study by Sianturi et al. in Papua, Indonesia, concluded that the development and implementation of placebased education in a remote elementary school in Highland of Papua has improved students' learning outcomes and confidence [13]. Preston [14] argues that outdoor and environmental education practitioners may benefit from moving away from a mode of teaching based upon 'generic' methods and look instead to a more local, specific and contextual form of education. Therefore, this study aims to analyze strategies for forest and Javan Lutung conservation through place-based pedagogy for primary school students. The strategy will serve as the guidance for developing a more detailed plan participatorily to be piloted in one elementary school around the BTSNP. Its implementation later on will provide more empirical evidence on the merits of place-based pedagogy in formal curriculum for environmental sustainability and conservation.

\section{METHODS}

To recommend the place-based pedagogy strategies using a SWOT analysis approach, various supporting information or data were collected such as the content of the current K13 Curriculum for elementary school, the perception of various stakeholders (school officials, BTSNP officials, and local people), and the potential locations where Javan Lutung can be easily observed.

To identify themes and learning goals in the K13 relevant for the Javan Lutung and forest conservation, we firstly read the theme title of a total of 51 themes across grade 1 to 6 . We looked for key words such as place, environment, living creature, animals and plants. We then skimmed the student's book and the teacher's book for themes that sounds relevant and noted the subthemes and its subsequent lesson goals.
Then we decided the most relevant theme(s) for each grade to be looked into more detail.

To explore stakeholders' perception, we conducted surveys to the following stakeholders: TNBTS officials, school teachers, and local people. Surveys were conducted through a face to face interview using a set of questionnaires. The questionnaire mainly comprised of closed-ended questions, supplemented by partially open-ended questions. It covered the following aspects: (1) Stakeholders' perceptions on Javan Lutung; (2) Stakeholders' favorability towards conservation education at schools; and (3) Demographic information of the surveyed individuals, including their basic socio-economic characteristics. Eight villages around the BTS-NP were purposively selected: Jarak Ijo, RanuPani, BendoLawang, Poncokusumo, Njajang, Wonorejo, Gubuklakah, and Pandansari (Figure 1). Around $15-20$ people were selected randomly from each village.

For Javan Lutung survey, line transect method [15] was used when the geographic condition was favorable. We sampled transects of $1 \mathrm{~km}$. We walked along each line, recording all monkey species that could be detected within the line as well as with the shortest distances from the line. When it was not possible to measure the perpendicular distance, we recorded the angle, then the perpendicular distances were calculated using trigonometry. When it was not possible to make line transect due to geographic conditions, we used transects that are already available, for example, using local people transect considering the encounter rate with the monkey. We recorded the number of individuals, age class distribution, GPS location and habitat characteristics. We estimated the number of groups and individuals of the species in the area. Replications was undertaken for each transects in order to achieve more accurate

data.

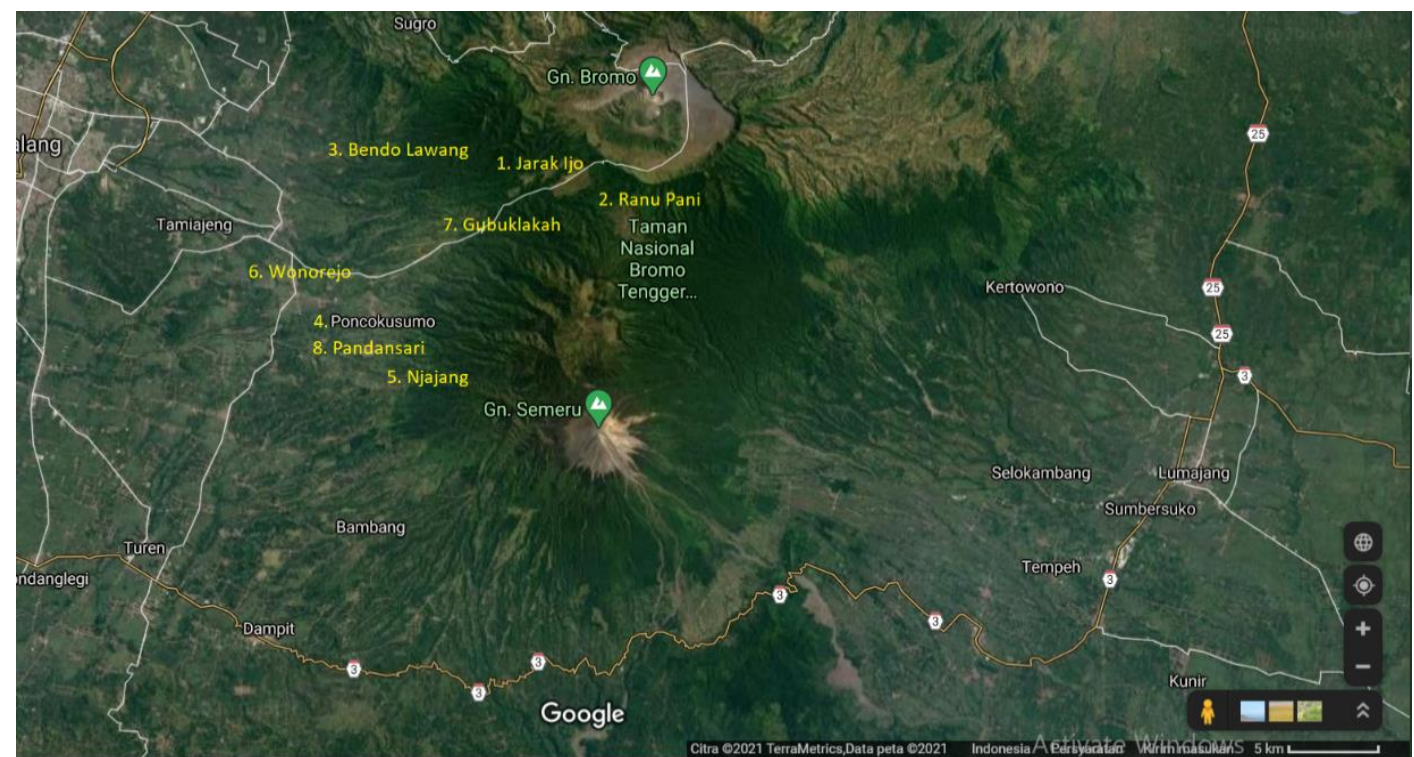

Fig. 1 Study location (Eight villages around the Bromo-Tengger-Semeru National Park) 


\section{RESULTS AND DISCUSSION}

\section{A. Review of K13 curriculum for elementary school}

Grade 1, 2 and 3 learn eight themes, while grade 4, 5 and 6 learn nine themes (Table I). Each theme comprises of three subthemes. Each subtheme consists of six lessons where each lesson has six learning goals. All grades have theme(s) that are relevant with nature conservation. We identified at least 12 themes that might be potential to be developed as placebased pedagogy to increase students' ecological literacy since young age.

However, considering the weather, it is safer for the outdoor trip to be conducted during the 1 st semester particularly the early themes (theme 1 to 3 ) as they are delivered in the month of July to September. Grade 6, theme 1 (Saving Living Creature), for example, is one of the ideal choices because it is delivered at the beginning of the semester (in July) and the subthemes are highly relevant with nature conservation (subtheme 1: Flora my friend, subtheme 2: Fauna my friend, and subtheme 3: Let's save fauna and flora). In this study, we provide examples on how Javan Lutung and forest conservation can be incorporated into formal education by implementing place-based approach. We will focus on Grade 6, Theme 1 Saving Living Creature, Subtheme 3 (Table II).

TABLE I. K13 CURRICULUM THEMES FOR ELEMENTARY SCHOOL

\begin{tabular}{|c|c|}
\hline $\begin{array}{c}\text { Grade } 1 \\
\text { Theme 1: Diriku (Me) } \\
\text { Theme 2: Kegemaranku (My hobbies) } \\
\text { Theme 3: Kegiatanku (My activities) } \\
\text { Theme 4: Keluargaku (My family) } \\
\text { Theme 5: Pengalamanku (My experience) } \\
\text { Theme 6: Lingkungan sehat, bersih dan asri (Healthy, clean, } \\
\text { and green Environment)* } \\
\text { Theme 7: Benda, hewan dan tumbuhan di sekitarku (Objects, } \\
\text { animals and plants around me)* } \\
\text { Theme 8: Peristiwa alam (Natural events) }\end{array}$ & $\begin{array}{c}\text { Grade } 2 \\
\text { Theme 1: Hidup rukun (Live in harmony) } \\
\text { Theme 2: Bermain di lingkunganku (Playing in my } \\
\text { environment) } * \\
\text { Theme 3: Tugasku sehari-hari (My daily tasks) } \\
\text { Theme 4: Hidup bersih dan sehat (Clean and healthy life) } \\
\text { Theme 5: Pengalamanku (My experience) } \\
\text { Theme 6: Merawat hewan dan tumbuhan (Caring for animals } \\
\text { and plants) * } \\
\text { Theme 7: Kebersamaan (Togetherness) } \\
\text { Theme 8: Keselamatan di rumah dan di perjalanan (Safety at } \\
\text { home and at road) }\end{array}$ \\
\hline $\begin{array}{c}\text { Grade } 3 \\
\text { Theme 1: Pertumbuhan dan perkembangan makhluk hidup } \\
\text { (growth and development of living things)* } \\
\text { Theme 2: Menyayangi tumbuhan dan hewan (Compassion for } \\
\text { plants and animals)* } \\
\text { Theme 3: Benda di sekitarku (Things around me) } \\
\text { Theme 4: Kewajiban dan Hakku (My responsibilities and my } \\
\text { rights) } \\
\text { Theme 5: Cuaca (Weather) } \\
\text { Theme 6: Energi dan perubahannya (Energy and its } \\
\text { transformation) } \\
\text { Theme 7: Perkembangan teknologi (Technology advancement) } \\
\text { Theme 8: Bumi dan alam semesta (Earth and the universe) }\end{array}$ & $\begin{array}{c}\text { Grade } 4 \\
\text { Theme 1: Indahnya kebersamaan (The beauty of togetherness) } \\
\text { Theme 2: Berhemat energi (Safe energy) } \\
\text { Theme 3: Peduli makhlu khidup (Caring for living creature)* } \\
\text { Theme 4: Berbagi pekerjaan (Sharing tasks) } \\
\text { Theme 5: Pahlawanku (My hero) } \\
\text { Theme 6: Cita-citaku (My future goal) } \\
\text { diversity in my country) } \\
\text { Theme 7: Indahnya keberagaman di negeriku (The beauty of } \\
\text { Theme 8: Daerah tempat tinggalku (The place where I live)* } \\
\text { Theme 9: Kayanya negeriku (My prosperous country)* }\end{array}$ \\
\hline $\begin{array}{c}\text { Grade 5 } \\
\text { Theme 1: Organ gerak hewan dan manusia (Motions } \\
\text { organs in animal and human) } \\
\text { Theme 2: Udara bersih bagi Kesehatan (Clean air for health) } \\
\text { Theme 3: Makanan sehat (Healthy food) } \\
\text { Theme 4: Sehat itu penting (Healthy is important) } \\
\text { Theme 5: Ekosistem (Ecosystem)* } \\
\text { Theme 6: Panas dan perpindahannya (Heat and its transfer) } \\
\text { Theme 7: Peristiwa dalam kehidupan (Events in life) } \\
\text { Theme 8: Lingkungan sahabat kita (Environment, our friend)* } \\
\text { Theme 9: Benda-benda di sekitar kita (objects around us) }\end{array}$ & $\begin{array}{c}\text { Grade 6 } \\
\text { Theme 1: Selamatkan makhluk hidup (Saving living } \\
\text { creature)* } \\
\text { Theme 2: Persatuan dalam perbedaan (Unity in diversity) } \\
\text { Theme 3: Tokoh dan penemuan (Public figure and invention) } \\
\text { Theme 4: Globalisasi (Globalisation) } \\
\text { Theme 5: Wirausaha (Enterpreneurship) } \\
\text { prosperity) } \\
\text { Theme 6: Menuju masyarakat sejahtera (Towards people's } \\
\text { Theme 7: Kepemimpinan (Leadership) } \\
\text { Theme 8: Bumiku (My Earth) } \\
\text { Theme 9: Menjelajah angkasa luar (Outer space exploration) }\end{array}$ \\
\hline
\end{tabular}

*Themes relevant with nature conservation 


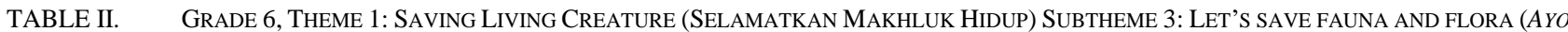
SELAMATKAN HEWAN DAN TUMBUHAN)

\begin{tabular}{|c|c|c|}
\hline Lessons and Relevant Learning Goal* & Current Topic/Exercise/Activity in the book* & $\begin{array}{l}\text { Opportunities to Incorporate Javan Lutung and } \\
\text { Forest Conservation }\end{array}$ \\
\hline $\begin{array}{c}\text { Lesson } 1 \\
\text { Learning goal 3: After reading text, } \\
\text { students can answer questions related to } \\
\text { animal conservation correctly. } \\
\text { Learning goal 4: After discussion, students } \\
\text { can report ways to save animals around } \\
\text { them properly. }\end{array}$ & $\begin{array}{l}\text { The texts in the book present information on Komodo, } \\
\text { Orang Utan and National Parks which are homes for } \\
\text { the two protected species. The texts further mention } \\
\text { the culprits of their habitats' destruction, one of them } \\
\text { is deforestation. } \\
\text { The discussion questions are: } \\
\text { What can we do to protect forest and its fauna? Why } \\
\text { do we need to protect the fauna? What are their } \\
\text { functions? } \\
\text { How about fauna near you? Are they protected? Find } \\
\text { and collect the information. } \\
\text { Let's Write task asks students to undertake } \\
\text { investigation to collect facts about a local fauna } \\
\text { species that is special in the area around them. } \\
\text { Students then write the results of their investigation, } \\
\text { including: the habitat characteristics, the function, its } \\
\text { population number, causes of decline, government } \\
\text { efforts to save it, and what can the students do to } \\
\text { protect the species. }\end{array}$ & $\begin{array}{l}\text { This section in the book has mentioned two } \\
\text { protected species and National Parks. It is a good } \\
\text { start to introduce them about the National Park } \\
\text { around them (i.e. The Bromo-Tengger-Semeru } \\
\text { National Park) and the protected species in there. } \\
\text { The activities (reading and discussion) can be } \\
\text { enriched with field trip to the nearby forest or } \\
\text { National Parks where they can undergo their } \\
\text { investigation as tasked in the Let's Write section. } \\
\text { The Let's Write section can be more flexible. They } \\
\text { can write a poem, a short story, or any piece of } \\
\text { writing they would like to make. }\end{array}$ \\
\hline $\begin{array}{c}\text { Lesson } 2 \\
\text { Learning goal 3: After reading stories, } \\
\text { students can find examples of Pancasila** } \\
\text { values implementation related to caring for } \\
\text { animals. }\end{array}$ & $\begin{array}{l}\text { The story in the book tells about a character named } \\
\text { Lina who has a cat as her pet. She loves her cat. } \\
\text { The students are asked to write their opinion on which } \\
\text { Pancasila values are performed by Lina. }\end{array}$ & $\begin{array}{l}\text { Values in Pancasila is an important aspect to build } \\
\text { students' character in Indonesia. Activity book can } \\
\text { be created so as to improve students understanding } \\
\text { on Pancasila values related to caring for fauna and } \\
\text { flora. }\end{array}$ \\
\hline $\begin{array}{c}\text { Lesson } 3 \\
\text { Learning goal 4: After discussion, students } \\
\text { can create a poster about fauna and flora } \\
\text { conservation with sufficient details. }\end{array}$ & $\begin{array}{l}\text { Let's Try task asks students to make a poster about } \\
\text { fauna or flora conservation around their area. } \\
\text { An example was provided on steps to draw some } \\
\text { faunas (chicken and fish) and flora (trees). }\end{array}$ & $\begin{array}{l}\text { The poster can be more locally-relevant to the } \\
\text { problems there. }\end{array}$ \\
\hline $\begin{array}{c}\text { Lesson } 6 \\
\text { Learning goal 6: After discussion, students } \\
\text { can make comics about caring for fauna } \\
\text { and flora. }\end{array}$ & $\begin{array}{l}\text { Students are asked to think about one Pancasila value } \\
\text { relevant with caring for fauna and flora. Students then } \\
\text { make a comic depicting the value. }\end{array}$ & $\begin{array}{l}\text { If making comics is difficult, this activity can be } \\
\text { replaced by giving the students a camera to capture } \\
\text { what they think is interesting when visiting the } \\
\text { forest/National Park. Then arrange the photos to } \\
\text { make a story. }\end{array}$ \\
\hline
\end{tabular}

\section{B. Stakeholders' Perception}

The total number of respondents from the local people is 157 (Figure 2) where 69\% are male and 31\% are female. The majority of them works as farmers $(78 \%)$ and $50 \%$ of them only studied until elementary school. The demographic information about the selected respondents is presented in Table III. Interviews to schools were conducted to five schools around the BTSNP. Four BTSNP officials were interviewed.

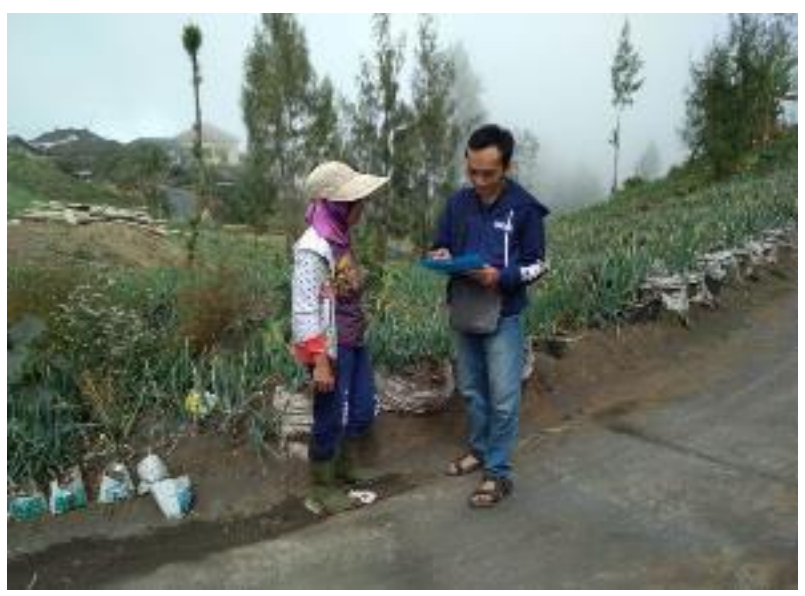

Fig. 2 Interview to local people
Stakeholders' perception on Javan Lutung population trend: Javan Lutung's population trend is declining steadily due to habitat loss, hunting and illegal capture [16].A survey conducted in 2018 by the Bromo-Tengger-Semeru National Park (BTSNP) in one of its Resort (i.e. Resort PTN Coban Trisula) found 36 individuals of Javan Lutung in the resort area.Most respondents in this study $(87 \%)$ perceived this species' population as decreasing, $10 \%$ steady and 3\% said don't know. We did not ask further to the respondents about what causes the decline.

Stakeholders' knowledge on Javan Lutung status: Javan Lutung is protected by the Indonesian government since 1999 through the Decision Letter of the Minister of Forestry and Estate Crops Number 733/Kpts-II/1999. It is also listed under the Convention on International Trade in Endangered Species of Wild Fauna and Flora (CITES) Appendix II. On question about whether Javan Lutung is currently a protected species or not, $94 \%$ said it is protected, while only $3 \%$ said not protected, and 3\% answered don't know.

Stakeholders' perception on if Javan Lutung is dangerous: Another important perception needs to be sought if we want to initiate conservation education especially involving young people is whether people think this species is dangerous. Our surveys showed that $78 \%$ of the people perceived that Javan Lutung is not dangerous, $13 \%$ thought 
Javan Lutung bites, 7\% said Javan Lutung destroys their crop, and $2 \%$ said don't know.

Stakeholders' perception on Javan Lutung's function: As herbivores, Javan Lutung disperse seeds throughout their habitat aiding aforestation. Through eating fruits, they help move seeds away from the parent plant, which prevents overcrowding of foliage within an area and also aids in forest growth [17]. Respondents' perceptions on Javan Lutung's function is presented in Figure 3. More than 50\% think that Javan Lutung has no ecological function. Only $10 \%$ understood its role as agent for seed dispersal. This enforced the need for conservation education. It is interesting to note that more than $25 \%$ of the respondents perceived Javan Lutung as tiger's food. This indicates that some respondents understood about the food chain in forest ecosystem. It can also be a selling point why we should conserve Javan Lutung and its habitat. If Javan Lutung disappears due to habitat loss, home and food for tigers will diminish and it would force tigers to go to nearby villages eating cattle.

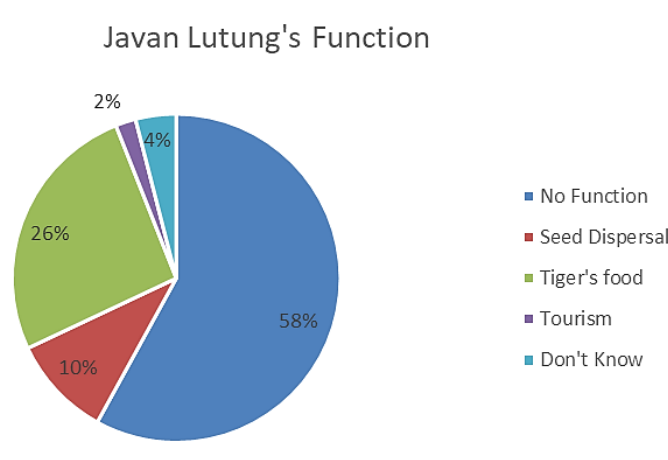

Fig. 3 Local people's perception on Javan Lutung's Function

Stakeholders' perception on forests functions: With regards to ecosystem services provided by the forest, most local communities are aware of forest function as water regulator (Figure 4). They stated that forests clearance will result in floods and landslides during the rainy season and drought during the dry season. Before people can engage in environmental programs, they need to be aware of the phenomenon and its impact on their wellbeing, perceive the seriousness of the problem, and develop positive attitude towards it [18]. Therefore, to increase the likelihood of it to be successful, future conservation education should take into account which forest function is deemed as the most important by the local community, in this case is forest function as water regulator.

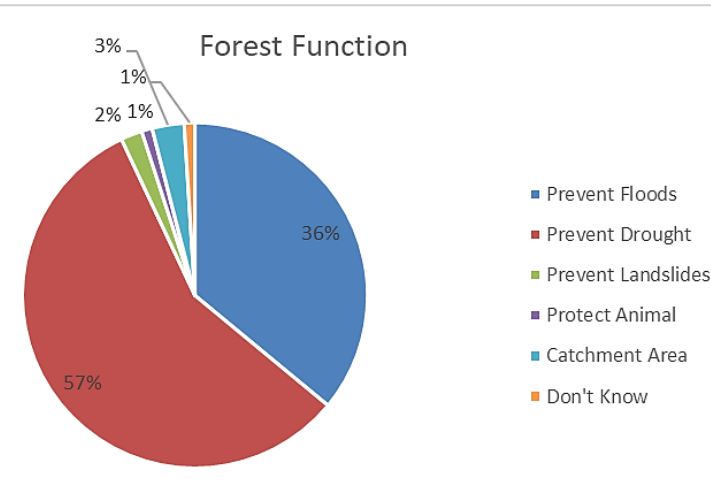

Fig. 4 Local people's perception on forest function

Stakeholders' perception on conservation education: When asked about whether conservation effort should be undertaken for Javan Lutung, around 79\% said 'yes', 18\% said 'no', and 3\% answered 'don't know'. In this question, the effort was not specified. Another question focusing on conservation of nature and wildlife to be taught in schools revealed that that all three main stakeholders are favorable towards conservation education be initiated at schools with more than $93 \%$ agreeing.

TABLE III. DEMOGRAPHIC INFORMATION OF THE RESPONDENTS

\begin{tabular}{|c|c|c|c|c|c|c|c|c|c|c|c|c|c|c|}
\hline \multirow[t]{2}{*}{ Village } & \multirow{2}{*}{$\begin{array}{l}\text { Number of } \\
\text { respondents }\end{array}$} & \multirow{2}{*}{\begin{tabular}{|c|} 
Age \\
$20-40$
\end{tabular}} & \multirow{2}{*}{$\begin{array}{c}\text { Gender } \\
41-55\end{array}$} & \multirow{2}{*}{$\begin{array}{c}\text { Occupation } \\
>55\end{array}$} & \multicolumn{10}{|c|}{ Education } \\
\hline & & & & & Male & Female & Farmers & Merchants & Other & Primary & $\mathrm{JHS}^{*}$ & SHS* & $\begin{array}{c}\text { Bachelor } \\
\text { Degree }\end{array}$ & $\begin{array}{c}\text { Did not } \\
\text { attend }\end{array}$ \\
\hline 1. Jarak Ijo & 20 & 5 & 8 & 7 & 14 & 6 & 20 & 0 & 0 & 11 & 5 & 0 & 0 & 4 \\
\hline 2. RanuPani & 20 & 8 & 5 & 7 & 13 & 7 & 17 & 3 & 0 & 11 & 6 & 0 & 0 & 3 \\
\hline 3. BendoLawang & 20 & 7 & 4 & 9 & 14 & 6 & 16 & 1 & 3 & 16 & 4 & 0 & 0 & 0 \\
\hline 4. Poncokusumo & 20 & 6 & 5 & 9 & 14 & 6 & 16 & 2 & 2 & 9 & 8 & 3 & 0 & 0 \\
\hline 5. Njajang & 20 & 7 & 8 & 5 & 13 & 7 & 15 & 2 & 3 & 15 & 5 & 0 & 0 & 0 \\
\hline 6. Wonorejo & 20 & 6 & 3 & 11 & 15 & 5 & 10 & 1 & 9 & 10 & 5 & 1 & 3 & 1 \\
\hline 8. Pandansari & 19 & 6 & 2 & 11 & 13 & 6 & 17 & 1 & 1 & 11 & 4 & 4 & 0 & 0 \\
\hline TOTAL RESPONDENTS & 157 & 56 & 36 & 65 & 108 & 49 & 123 & 14 & 20 & 88 & 41 & 12 & 4 & 12 \\
\hline Percentage & 100 & 35,67 & 22,93 & 41,4 & 68,79 & 31,21 & 78,344 & 8,9172 & 12,739 & 56,051 & 26,11 & 7,643 & 2,54777 & 7,6433 \\
\hline
\end{tabular}

Source: Primary data, 2019

*Junior High School

**:Senior High School

\section{Javan Lutung Survey}

Surveys were conducted on August 2019. The surveys identified 20 species of primates' vegetation diets and 3 vegetations for primate's cover. We found that Javan Lutung are distributed in Coban Trisula Resort, Jabung Resort, Ranu Pani Resort, Senduro Resort, and in Perhutani forest in
Poncokusumo village. Figure 5 shows one of the individuals spotted during the surveys. This study found that there are two potential sites to be developed for the education-tourism taking into account the Javan Lutung's distribution, topography and distance from the entrance. 


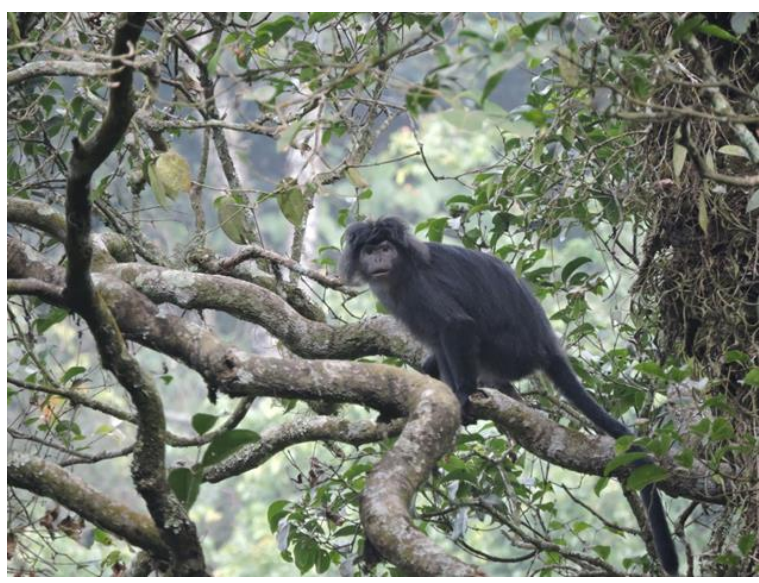

Fig. 5 Javan Lutung in Bromo-Tengger-Semeru National Park

(Photo by I. Y. Agustin, 2019)

Potential Site 1: Forest area in Poncokusumo Village owned by Perhutani, a state-owned company.

This area is frequently visited by elementary school students, junior high school students, and youngsters to enjoy the nature there. This site is also used as camping ground. From the survey, we encountered two groups of Javan Lutung around this area. The groups are often seen but are still wild and timid. Their sounds can be frequently heard from this area. However, this area is far from the main road (around $2.5 \mathrm{~km}$ from the main road) and access to this area is rather difficult.

\section{Potential Site 2: Coban Trisula Resort in the BTSNP.}

The access to Resort Coban Trisula is relatively easy as it is situated next to main road (Figure 6). A waterfall in this site is already becoming one of the main tourist destinations. Trails are already in place to get to the waterfall. While walking on the trails, visitor can learn about trees and observe Javan Lutung. We encountered five groups of Javan Lutung where two of which are familiar with human presence. This is an asset should stakeholders want to develop education activities related to wildlife behaviour observation. The challenge here is this site is too close to the main road where traffic intensity is quite high. Hence, if the activities involve children, a good surveillance must be applied. In addition, there are abysses which also needs careful attention. Illegal poachers are afraid to enter this area due to massive surveillance in this area and the presence of BTSNP resort office.

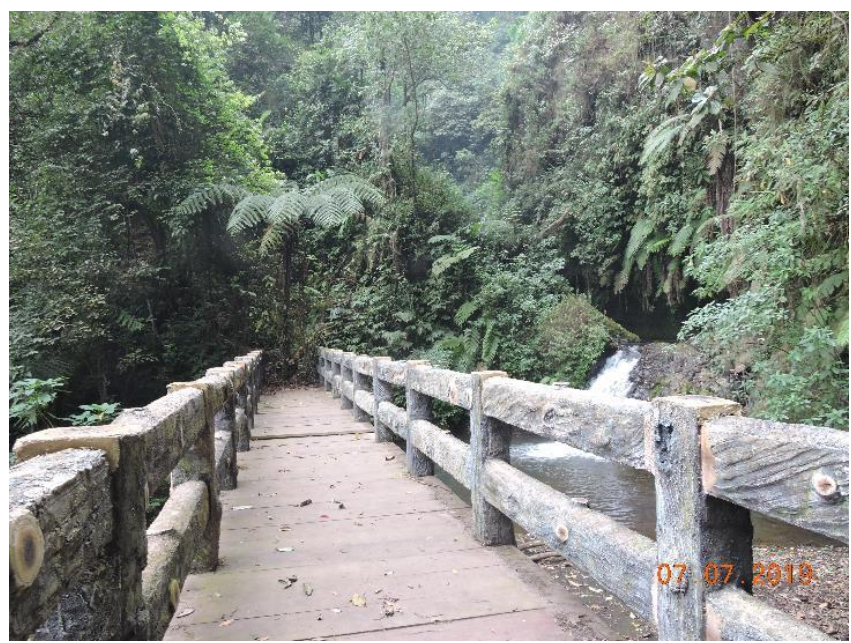

Fig. 6 Forest trails in Coban Trisula Resort (2019)

\section{SWOT Analysis}

Based on the information collected from K13 Curriculum review, stakeholders' interview results and Javan Lutung distribution surveys, below are five major strengths, opportunities, weaknesses and threats identified (Table IV).

\section{TABLE IV. THE RESULTS OF SWOT ANALYSIS}

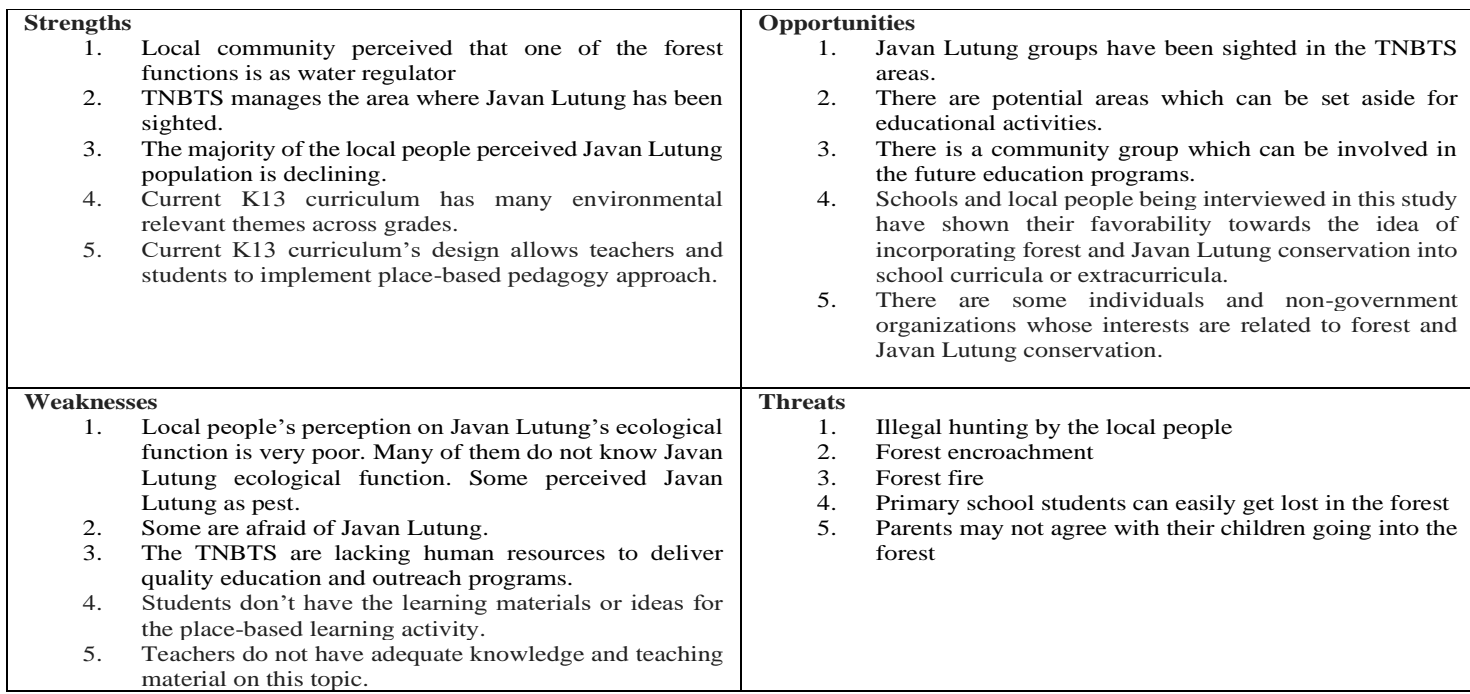

Based on the SWOT analysis, below are our recommendations on how place-based pedagogy can be incorporated into schools' curriculum in order to contribute to the Javan Lutung and forest protection.
S-O Strategy. Javan Lutung and forest conservation can be taught in various themes in K13 curriculum with some outdoor activities. Outdoor activities can be designed in the two potential locations identified in this study. Study by 
Somerville and Green [19] on ecological learning in primary school shows that through outdoor activities, students engage with the more-than-human world which co-exist alongside humans enabling them to become more empathetic and considerate.

S-T Strategy. We recommend that the education program be built on forest function as water regulator as this is the issue that the local community can relate to. This issue will be easily grabbed by the local people because they have seen how forest clearing has caused flooding in their area. Other ecosystem services provided by the forest could be a secondary goal to be taught during the educational activities. In addition, the education program should visualize Javan Lutung's ecological function related to its function in seed dispersal in the forest. Since the interviews revealed that the local people do not know about Javan Lutung's ecological function, part of the education activity should be able to visualize this clearly.

W-O Strategy. NGOs, schools and BTSNP develop activity book and learning materials. Important concept on participatory creation of a place-based teaching and learning methodology presented by Tsevreni and Panayotatos [20] can be consulted when developing the materials. With the current policy in university's curriculum in Indonesia called "Merdeka Belajar: Kampus Merdeka" translated as "Freedom to Learn: Independent Campus [21], university students can develop their project to support place-based pedagogy. Placebased pedagogy is becoming more relevant during the pandemic where most schools and universities are closed.

W-T Strategy. Key principles of place-based education include the need for learning to arise from experience of and in local contexts and to take a problem-solving approach [22]. Teachers are often facing barrier in implementing placebased pedagogy. One of the barriers is teachers' capacity to undertake such activities [23,12]. To overcome this, the place-based pedagogy curriculum can be led by NGO in collaboration with BTSNP and the teacher. A well-structured education program should focus on improving the teachers' knowledge and skills first before embedding the conservation education into the schools' activities. Capacity building for the BTSNP staffs regarding the management of education tourism site and activities is recommended. A more detailed plan for the education program needs to be developed and it will help identifying where more training is needed. To improve safety, clear standard operations procedure must be in place.

This study suggests that performing a SWOT analysis taking into account stakeholders' perception, as argued by Bayard and Jolly [18], has allowed the formulation of a more strategic nature conservation education using place-based pedagogy approach to overcome the issue of environmental education being temporary and ineffective as stated by Parker [3]. Future research on the process and impacts of implementing these strategies will enrich the much-needed literature on effective environmental education integration into formal education.

\section{CONCLUSION}

This study discussed strategies to incorporate Javan Lutung and forest conservation into elementary students' learning process at school through a place-based pedagogy approach. This study concluded that a place-based approach is feasible to be conducted because (i) from interviews to stakeholders, the majority of the stakeholders supports the idea of forest and Javan Lutung conservation to be taught at school, (ii) from the Javan Lutung survey, two potential locations have been identified where Javan Lutung can easily be observed, (iii) from curriculum review, we found that there are many themes in each grades relevant to nature conservation. The most important point from the strategies is collaborations. Furthermore, our reviews on the Indonesian national curriculum indicated that the K13 curriculum provides opportunities for students and teachers to be more locally contextual in their learning process. This good opportunity should be exercised by conservation education advocates to answer the challenge of ineffective environmental education in the formal education sector in Indonesia.

\section{ACKNOWLEDGEMENT}

We would like to thank the Bromo-Tengger-Semeru National Park, the local people around the National Park, and the school officials participating in this study. The financial support from the Rufford Small Grants Foundation is greatly appreciated.

\section{REFERENCES}

[1] IUCN, "The IUCN Red List of Threatened Species. Version 2019-3. ISSN 2307-8235.” 2019.

[2] L. Smith, S. Broad, and B. Weiler, "A Closer Examination of the Impact of Zoo Visits on Visitors Behaviour," J. Sustain. Tour., vol. 16, no. 5, pp. 544-562, 2008.

[3] L. Parker, "Environmentalism and education for sustainability in Indonesia," Indones. Malay World, vol. 46, no. 136, pp. 235-240, 2018, doi: 10.1080/13639811.2018.1519994.

[4] L. Parker and K. Prabawa-Sear, Environmental education in Indonesia. Creating responsible citizens in the global south? London: Routledge, 2019

[5] D. Sobel, Place-based Education: Connecting Classroom and Community. MA: The Orion Society: Great Barrington, 2004.

[6] A. L. Powers, "An Evaluation of Four Place-Based Education Programs," J. Environ. Educ., vol. 35, no. 4, pp. 17-32, 2004, doi: 10.3200/JOEE.35.4.17- 32.

[7] P. Theobald, Teaching the Commons: Place, pride, and the renewal of community. Boulder, CO: Westview Press, 1997.

[8] D. W. Orr, Ecological literacy: Education and the transition to a postmodern world. Albany, NY: State University of New York, 1992

[9] G. Smith, "Place-based education: Learning to be where we are," Phi Delta Kappan, vol. 83, pp. 584-594, 2002.

[10] Sustainable Development Commission, Every Child's Future Matters, 3rd ed. London: Sustainable Development Commission. 2009.

[11]K. Malone, "Every Experience Matters: An Evidence Based Review of the Role of Learning Outside the Classroom on the Development of the Whole Young Person," 2008.

[12] Y. Telaumbanua, "Analisis Permasalahan Implementasi Kurikulum 2013," J. Polingua Sci. J. Linguist. Lit. Educ., vol. 3, no. 1, pp. 86108, 2018, doi: 10.30630/polingua.v3i1.25.

[13]M. Sianturi, C. Chiang, and A. A. Hurit, "Impact of a Place-Based Education Curriculum on Indigenous Teacher and Students," Int. J. Instr., vol. 11, no. 1, pp. 311-328, 2017, [Online]. Available: https://files.eric.ed.gov/fulltext/EJ1165222.pdf.

[14]L. Preston, "Making connections with nature: Bridging the theory practice gap in outdoor and environmental education," J. Outdoor Environ. Educ., vol. 8, pp. 12-19, 2004, doi: https://doi.org/10.1007/BF03400791.

[15]S. Buckland, J. A. Plumptre, L. Thomas, and E. A. Rexstad, "Design and Analysis of Line Transect Surveys for Primates," Int. J. Primatol., vol. 31 , no. 5 , pp. $833-847,2010$. 
[16] V. Nijmann and J. Supriatna, "Trachypithecus auratus. The IUCN Red List of Threatened Species," 2008.

[17]New England Primate Conservancy. Javan Langur. neprimateconservancy.org. https://www.neprimateconservancy.org/javan-langur.html, accessed 30 Dec 2020.

[18]B. Bayard and C. Jolly, "Environmental Behavior Structure and SocioEconomic Conditions of Hillside Farmers: A Multiple-group Structural Equation Modeling Approach," Ecol. Econ., vol. 62, pp. 433-440, 2007.

[19]M. Somerville and M. Green, "A pedagogy of 'organized chaos' Ecological learning in primary schools," Child. Youth Environ., vol. 21, no. 1, pp. 14-34, 2011.

[20]I. Tsevreni and E. Panayotatos, "Participatory Creation of a PlaceBased Teaching and Learning Methodology for Children's Participation and Citizenship in the Urban Environment," Child. Youth Environ., vol. 21, no. 1, pp. 293-209, 2011.

[21]Kemendikbud, "Buku Panduan Merdeka Belajar: Kampus Merdeka." Jakarta: Direktorat Jenderal Pendidikan Tinggi Kemdikbud RI, 2020.

[22]G. Mannion and C. Adey, "Place-based education is an intergenerational practice," Child. Youth Environ., vol. 21, no. 1, pp
$35-58$
2011 ,
[Online].
Available: https://www.jstor.org/stable/10.7721/chilyoutenvi.21.1.0035\%0AJSTO R.

[23]A. Bird, "The Potential for Place-Based Pedagogy in Irish Primary Schools," M.S. thesis, National University of Ireland, Galway, 2017. 